\title{
Privatization of Bulk Terminal Operations and its Efficiency: The Case of Durres Port
}

\author{
OSMAN METALLA \\ Aleksander Moisiu" University of Durres Albania. \\ Email: osman.metalla64@gmail.com \\ EMIRJANA VATA \\ Aleksander Moisiu" University of Durres Albania. \\ SHPETIM PUPA \\ Aleksander Moisiu" University of Durres Albania.
}

BLEDI KACADEJ

Tetra computers, Albania.

\begin{abstract}
Durres port is the main gateway to Albania and is one of the most important economic generators of the country. During the last couple of decades, this port has undergone a number of infrastructural and institutional transformations. All these investments and reforms have affected the port performance making it, a more modern and competitive port in the region. This paper aims at analyzing the effects of the institutional reforms in the improvement of the operational performance of the dry bulk cargo terminal of the port of Durres. These reforms combined with infrastructural investments have made the terminal and the port more competitive, environmentally friendly, safer and securer in all terminal operations. Based on the studied literature, statistics of the port and terminal, a comparison analyses are performed in order to compare the performance of the terminal before and after the privatization process. Comparisons are made among different PPI. The port at large, and the terminal itself have undergone a deep reformation and terminal performance indicators have been significantly improved. Apart of that, there is still room for improvement, regarding specific indicators, such as loading and unloading rate, environmental, safety and security standards of the terminal.
\end{abstract}

Keywords: Terminal, Terminal Performance Indicators, Reforms, Concession.

\section{Introduction}

Port of Durres is the biggest port of Albania and is situated on the SE part of the Adriatic Sea. It is the gateway of the Corridor VIII to Albania and further to Eastern Balkans. This port is $36 \mathrm{~km}$ west of the capital Tirana. The port handles roughly $78 \%$ of the country's seaborne cargo in tonnage terms and $75 \%$ of all export and import trade of the country, servicing container ships, ferry boats, Ro-Ro vessels, general cargo vessels, bulk cargo and a few fuel vessels. The port has 80 ha of surface area, and around $2250 \mathrm{~m}$ of quay including 11 quays varying in length from $30 \mathrm{~m}$ to $295 \mathrm{~m}$, and with a water depth varying from 7.5 $11 \mathrm{~m}$. According to the development Master Plan of 2008 the port had to have a land use plan with different development alternatives. The alternative selected by the Port of Durres Authority (PDA) was to develop the port in specialized terminals. Actually, the port is divided in four main terminals as follows: 
- West terminal, which is mainly dealing with general cargoes, and grain handling. This is the only terminal that is being operated by Port Authority. This terminal is located from berth $1-5$.

- Containers terminal is situated in the northern part of the port. This terminal is located at berths No. 6 , 7 and 8 (part of terminal 8 belongs to ferry terminal). The total quay length of the terminal is $450 \mathrm{~m}$. The area of the terminal is approximately $60.000 \mathrm{~m}^{2}$.

- Ferry terminal is located in berths No 8 and 9. The total area size of the terminal is about 10 ha.

- Eastern terminal or the dry bulk terminal is located in the eastern side of the port. The total quay length is about 250 meters and this is the deepest terminal of Durres port, which allows the accommodation of bigger vessels. This terminal is mainly handling cement, clinker, minerals and the imports of coal and exports of different materials, scrap.

Port of Durres has good road connections to the national and international road network. There is no rail link from the port terminals. The only terminal, which has rail connection, is east terminal. This terminal is dedicated to dry bulk cargoes.

Apart of the land use plan, the port had to go other reforms in order to meet the objectives of the WB in order to transform the port from a public port into a landlord port. To this end, today three out of four terminals are concessions given to different companies but the west terminal, which is still being operated by PDA. In this terminal there are three stevedoring companies. This paper will analyze the performance of the east terminal before and after the terminal was given out to the concessioner in order to check the benefits, and the weak points of the concession.

\section{East Terminal}

Bulk cargo or otherwise east terminal is specialized in bulk cargo handling. This terminal has the deepest quay water side which goes up to $11 \mathrm{~m}$ deep, but due to the restrictions of the entrance channel, the size of the ships that are being handled at this terminal does not represent the maximum capacity of the terminal. The maximum draft the ship can be accepted at Durres Port is about 7,5 meters (according to the last declaration of the General maritime Directorate of May 2018), therefore the terminal could not use the water depth advantage due to this restriction. The terminal has a yard area of $250.000 \mathrm{~m}^{2}$, and still there are possibilities for expanding this area. This area is mainly used to stock the arriving cargoes or the cargoes waiting to be loaded. The terminal includes quays 10 and 11 with a total length of 500 meters. This terminal has a good rail connection. The total rail length is $1550 \mathrm{~m}$, of which $370 \mathrm{~m}$ are laid in the transit yards.

Since 2013 the terminal has been operated by EMS-APO. The main commodities in this terminal are iron ore, concentrate, coal, scrap etc. This contract was concluded on May 2013 between the Ministry of Public Works and Transport as the contracting authority and the Contractor EMS Shipping \& Trading GmbH. According to this concession contract, the contractor, has the right of management, operation, construction and maintenance of the terminal, technical improvement and adaption in order to meet the present and future traffic demand of the East Terminal. The operation of the terminal will include loading and unloading of the dry bulk cargoes, minerals, coal etc., and the terminal will be able to handle the general cargo vessels as well, if the need will be. This contract has a time span of 35 years. The Ministry of Public Works and Transport and Durres Port Authority have established a concession implementing unit and their aim is monitoring and performance measurement of the concessions of the Durres Port. Monitoring or measuring the terminal performance will not interfere in the methods or operations of the concessionaire but will be carried out through KPI-s. This means that monitoring or performance measurement will be carried out through monthly or annual reports that the contractor will deliver to the Port Authority or the Ministry. Based on the reports and data gathered through concessionaire and DPA, this paper analyses the performance of the terminal before and after the period of concession. 


\section{Cargoe Volumes in Terminal}

East terminal handles export and import dry cargoes. The main cargoes handled are: coal, minerals (iron ore, nickel etc.), cement in bulk, scrap and others. Based on the data gathered from DPA, the key performance indicators for the east terminal are as shown in the following table 1.

Table 1. Key performance indicators for East Terminal, Port of Durres

\begin{tabular}{|c|c|c|c|c|c|c|c|}
\hline Year & $\begin{array}{c}\text { Number } \\
\text { of ships } \\
\text { that have } \\
\text { called } \\
\text { terminal }\end{array}$ & $\begin{array}{c}\text { Average } \\
\text { waiting time } \\
\text { in roadstead } \\
\text { (hrs) }\end{array}$ & $\begin{array}{c}\text { Average } \\
\text { time } \\
\text { alongside } \\
\text { quay (hrs) }\end{array}$ & $\begin{array}{c}\text { Average } \\
\text { working } \\
\text { time } \\
\text { (hrs) }\end{array}$ & $\begin{array}{c}\text { Occupancy } \\
\text { of the } \\
\text { terminal } \\
\text { (days) }\end{array}$ & $\begin{array}{c}\text { Volume of } \\
\text { cargo } \\
\text { handled } \\
\text { (tons)*** }\end{array}$ & $\begin{array}{c}\text { Average } \\
\text { tonnage } \\
\text { per ship } \\
\text { (tons) }\end{array}$ \\
\hline 2011 & 128 & 36,96 & 53,76 & 40,32 & 289,56 & 678.656 & 5302,3 \\
\hline 2012 & 161 & 31,92 & 68,14 & 52,08 & $459,56 *$ & 714.679 & 4439 \\
\hline 2013 & 79 & 17,76 & 47,76 & 34,08 & 157,17 & 552.289 & 6991 \\
\hline 2014 & 124 & 12,14 & 49,20 & 38,64 & 256,43 & 876.686 & 7070 \\
\hline 2015 & 74 & 14,25 & 55,92 & 41,76 & 165,08 & 526.179 & 7110 \\
\hline 2016 & 61 & 10,35 & 60,48 & 47,04 & 165,00 & 418.857 & 6866 \\
\hline 2017 & 103 & 09,53 & 52,80 & 40,80 & 270,97 & 738.755 & 7172 \\
\hline
\end{tabular}

Source: Durres Port Authority Statistical data/ Albanian Port operator (APO)

*The total number of days for year 2012 is bigger than 365 because the terminal was not privatized yet and the figure represent the occupation of quays $2,7,8,10 \& 11$ of the port where the bulk cargoes were handled.

**This column shows the total volume of the cargo handled in the terminal (export + imports).

As it can easily be observed from the above table, some of the performance indicators such as average waiting time of the ship, average tonnage per ship or the overall terminal cargo handled and the average waiting time at the roadstead are indicators that are not dependent of the terminal. Other indicators such as average time alongside quay, or average working time are directly related to the terminal performance and indicate the performance of the terminal during different years before and after the concession.

\section{Discussion}

The volumes of the cargoes have fluctuated according to the countries traffic demand on the bulk cargoes. The specialization of the port in different terminals has affected the volumes of the cargoes that are being handled in the east terminal. Before the concession, bulk cargoes could be handled almost in any place within harbor, starting with quay No1, 2, 5, 6, 7, 10,11. After the port was separated in terminals, each terminal was specialized for a set of cargoes. therefore, the cargoes that are handled now in east terminal are mainly minerals, coal, scrap and other bulks.

The following chart gives a clear picture of the trends of the bulk cargoes during the recent years.

This chart shows that there is a strong increase of $58,7 \%$ of the cargoes handled in Durres port from year 2013 to 2014. This looked like a very positive turn in terminal performance and this increase was attributed to the new ownership of the terminal. But this growth was followed by a change in trend from increasing to a significant reduction of the cargoes handled in this terminal during year 2015. The reduction was about $40 \%$ of comparing to the previous year. The volumes continued to shrink even in the following year 2016 and the decrease of the cargo volume was about 40\% comparing to year 2014, and from year 2015 to 2016 this reduction was $21 \%$. This reduction was as the consequences of the economic crises. The economic 
growth was slowed down and this was reflected in the export and import demand. Year 2017 was a very good year and the overall traffic volume was increased at 76\% comparing to year 2016.

Chart1. Volume of the cargo handled in East Terminal.

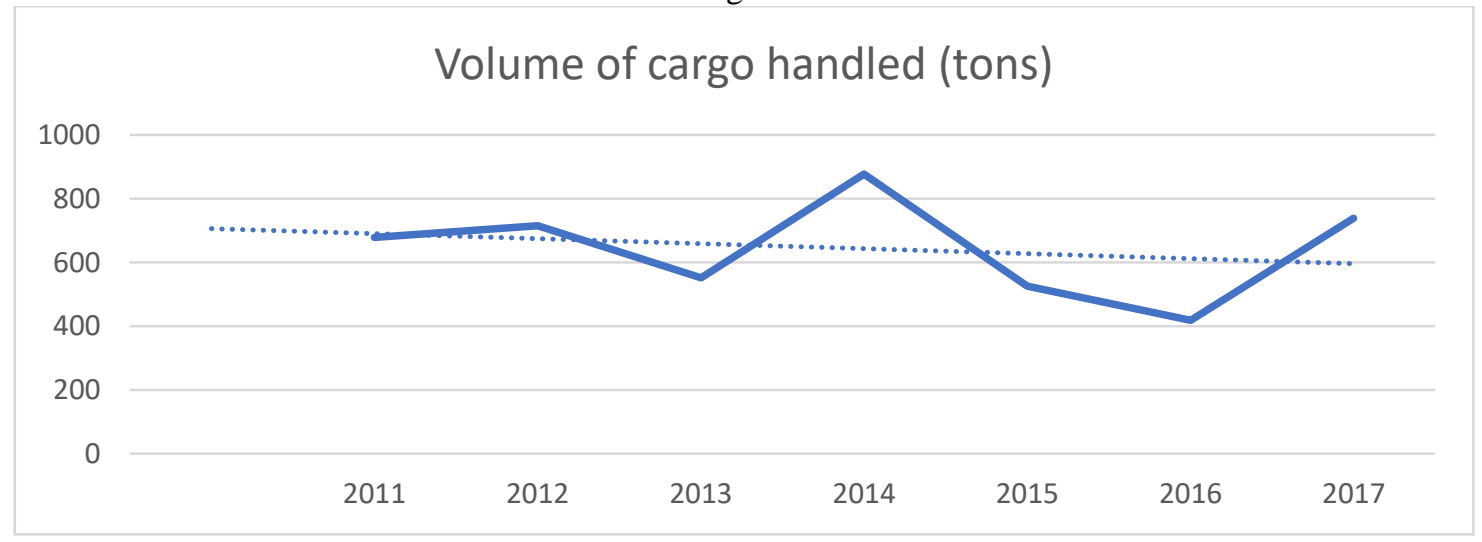

Source: adopted by the author

Another indicator of the terminal is that the ship size has been increased during the course of the years. Initially in year $2011-2-12$, the average size of the vessel calling the terminal was about $4500-5000 \mathrm{dwt}$, and this size has been increasing year after year. Actually, the average size of the ship belongs to the tonnage of $7170 \mathrm{dwt}$, about $2000 \mathrm{dwt}$ bigger than seven years ago. This is in line with the global tendency of the ship size. Because of the economy of scale, ship size tends to be bigger, and this means lower transport fees.

One of the most important key performance indicator is the average working time of the ships while alongside the quay. The following chart 2 shows that the average time has been reduced, while the ship average size has been increased. This means that a bigger ship has been handled (loaded/unloaded) practically almost at the same time, therefore we have a better terminal performance.

Chart 2. Average working time and the size of the ships

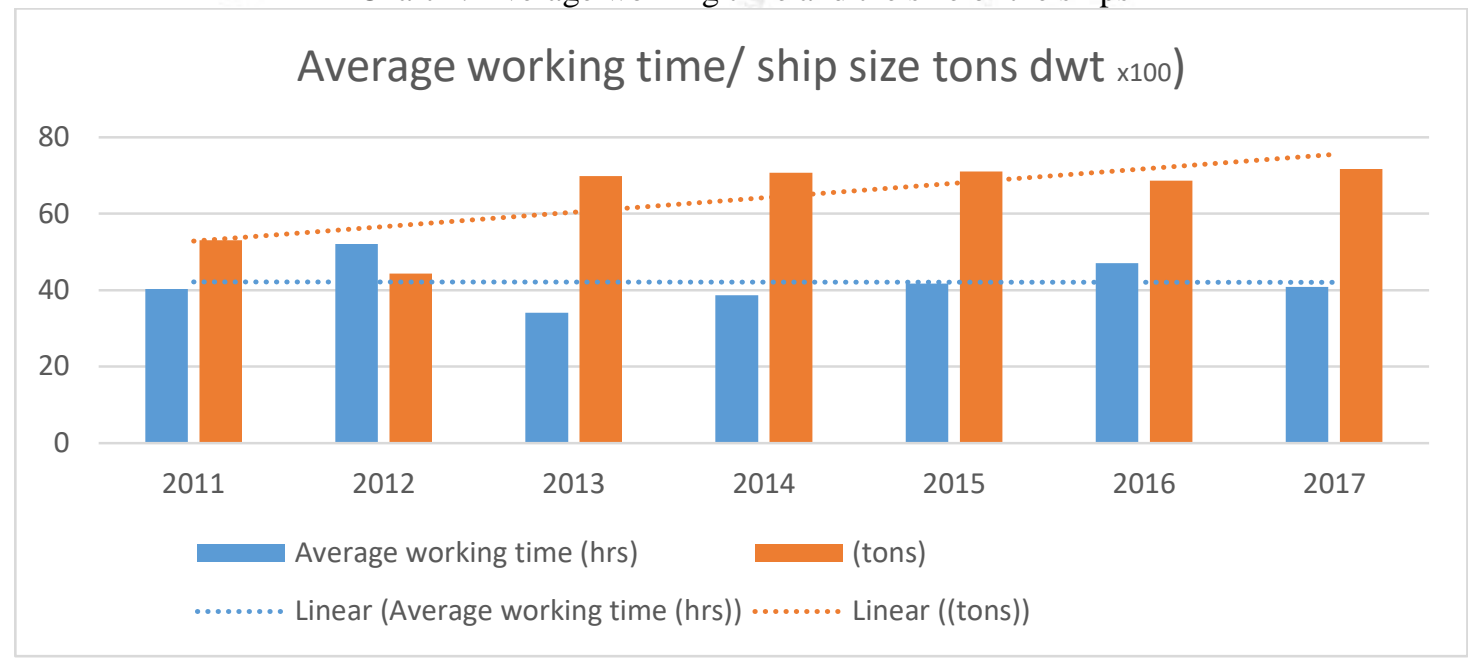

Source: adopted by the author

Terminal occupancy rate shows the time terminal has been occupied in a year. According to data available, it results that the terminal occupancy has variated during years and this is due to the import and exports 
demand. Because of the economic crises this demand has been significantly reduced during years 2015 and 2016 followed by a sharp increase in 2017. This is in linear relationship with the occupancy of the terminal. The following chart No.3 shows the daily volumes handled in the terminal

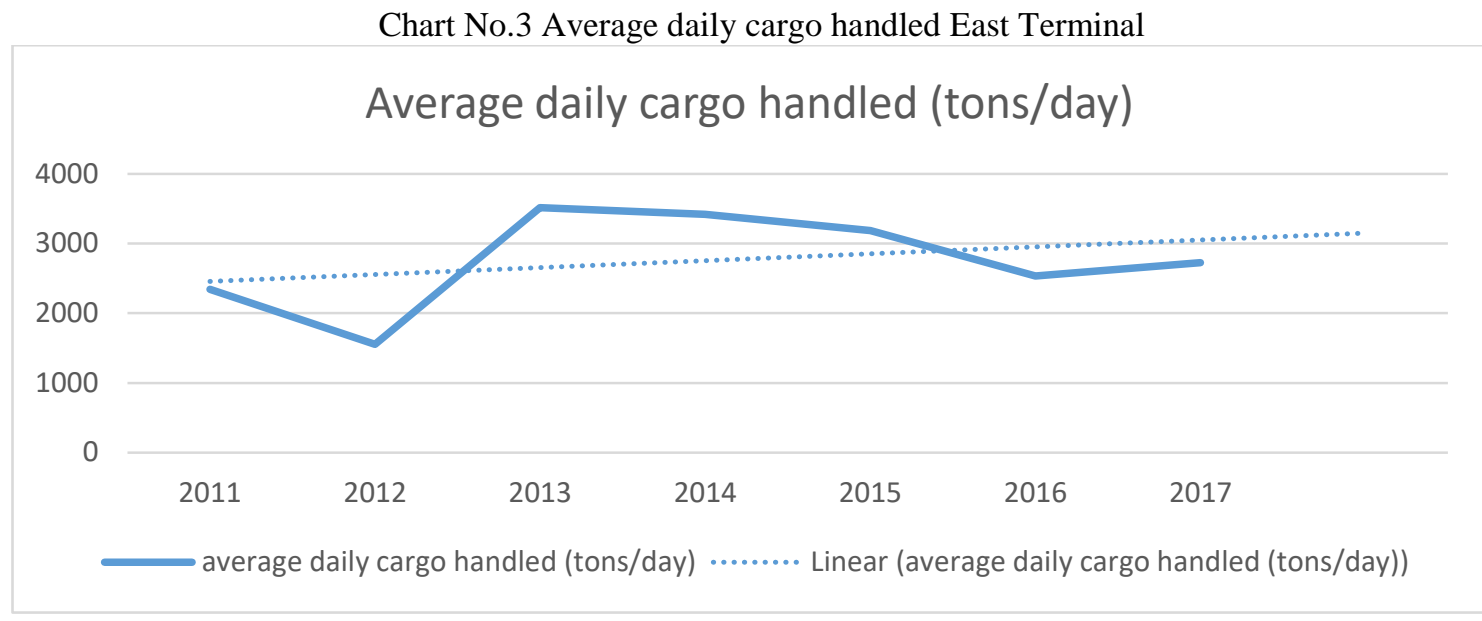

Source: adopted by the author

According to the values in chart No. 3 we realize that daily handling rate has been increased after the terminal has been privatized. The performance of the new operator is shown directly in the first year where we can observe a sharp improvement of the daily handling rate. Before the privatization the terminal could handle about 2350 tons of cargo per day (loading/unloading), and after privatization this figure averages about 3000 tons daily or with an increase of more than $27,6 \%$ comparing to the period before the privatization. The rail connection that the port has with rail network is a big advantage and contributes to the performance of the terminal, but again there is still potential for performance improvement. The overall condition of the national rail network is in very poor condition and the safety of the network is far from standards. This makes transport operators and logistic offers to use more the road transport than rail one. This means that the transferring of the cargo from terminal is affected from the conditions of the rail network. When the rail network will be reconstructed and in full capacity operation, there are possibilities for terminal to improve its daily handling volumes.

Another very important performance indicator is the average waiting time of ships in roadstead. During the last years this factor has been improved dramatically. In year 2011, the average waiting time of a ship that arrived in Durres port was about 36,96 hours. That was because the port was working with low loading unloading rates, there were too many ships flying Albanian flag that considered Durres port as their home port, occupying quays of the port even when they were out of order or carrying no loading/unloading operation at all. Another factor was that the containerization was not as developed as today and still a great share of the cargo in Durres port arrived in conventional general cargo vessels.

The ships were berthed normally where there was a free spot, and there was no real specialization of the terminals. That created difficulties in having high handling rates, therefore sometimes ships had to wait for days in the roadstead. Division of the port in specialized terminals has contributed in the improvement of the handling rate of the port. The growth of the containerized cargoes was another factor which contributed in a better port performance. All these factors, have positively contributed in cutting down the waiting time of the ships in roadstead. Apart of all these operational factors, there is another very important factor we have to mention. Government agencies operating in port such as customs, border police and Harbor master's office, have improved their performance and are more flexible in carrying out the arrival formalities in a shorter time. 
Chart No. 4 Average waiting time of arriving ships at roadstead

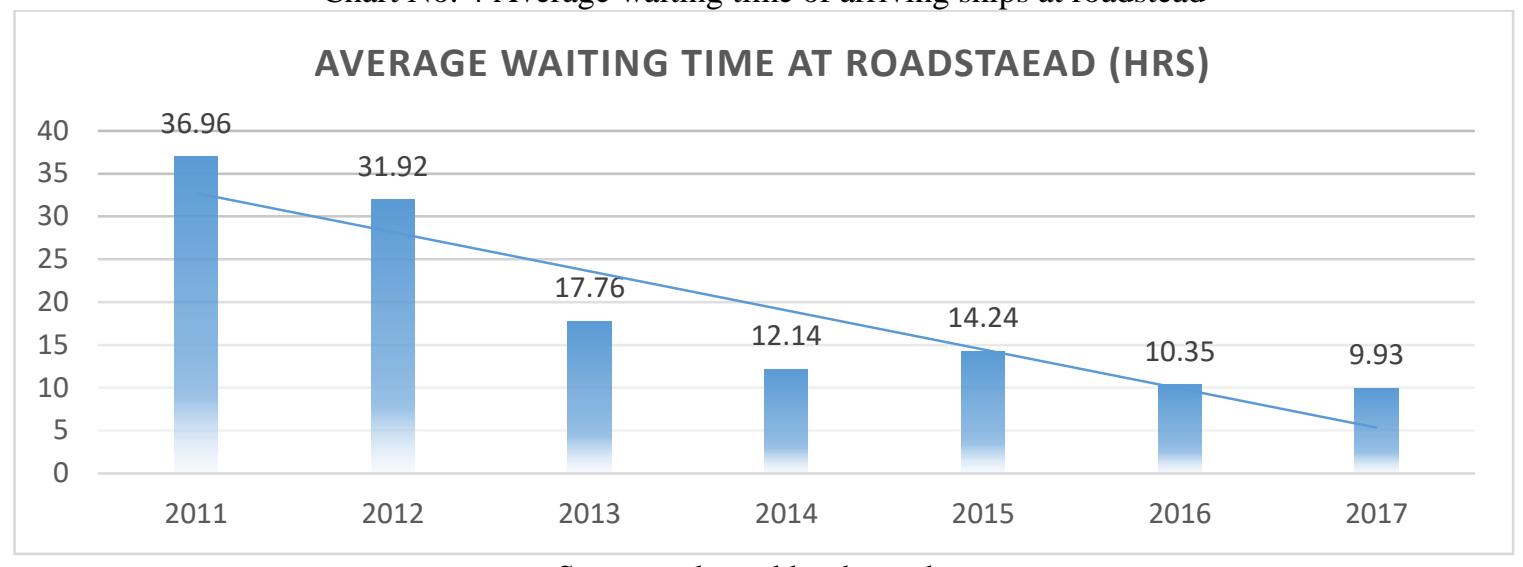

Source: adopted by the author

As it can easily be observed from chart No. 4 the waiting time of the ships in year 2017, has been reduced almost 4 times comparing to year 2011. Even though this might be considered more a port performance indicator than a terminal one, still it is related to the overall time a ship spends in Durres. And for a ship that is headed to the East terminal (bulk terminal), the overall time from dropping the anchor up to the time ship leaves the port, this factor is important. The more we reduce the waiting time of the ship, the better is the rate between the overall time and the working time. The final objective of any port and terminal is to reduce in maximum the difference of the overall time of the ship with the working time alongside quay. Therefore, we should say that this performance indicator has been improved in a significant way, making this terminal, and the port at large with a better performance.

\section{Conclusions}

This paper has evaluated some of the performance indicators of the East Terminal (bulk cargo) of Durres port. This terminal has been privatized 5 years ago, in May 2013 and the operator is Contractor EMS Shipping \& Trading GmbH. Based on the cargo handled in the terminal during the years before and after the privatization, we have reached in the following conclusions:

- The cargo volumes of the terminal are directly related to the economic development of the country. The economic development defines the traffic demand; therefore the cargo handled in the terminal is a dependent variable of the economic development. That was clearly demonstrated during years 2014-2015 where the economic development of the country was slowed down, and the cargo volumes dropped drastically. During 2016, with the improvement of the economic performance of the country, the volumes were increased significantly.

- The performance of the terminal after the privatization has been improves. This is shown in the increase of the daily loading/unloading rates and the growing of the ship size resulted in no increase of the working time. Even though the ship size was increased from 5302 dwt in 2011 to $7172 \mathrm{dwt}$ in 2016 the working time of the ship alongside the terminal was almost unchanged. This means that for the same time unit the terminal handled more cargo.

- The waiting time of the ships in roadstead has been drastically reduced, therefore improving the rate between overall time of the vessel in the port and the affective time of the vessel (working time).

The privatization of the terminal and the specialization of the operations, has contributed positively in improving the overall terminal performance indicators. There is still room for improvement of these 
indicators together with safety, security and environmental indicators. This privatization has proved to be efficient and positive.

\section{References}

Ng, A K. Y. \& Pallis, A A, 2010. Port governance reforms in diversified institutional frameworks: generic solutions, implementation asymmetries. Environment \& Planning.

O. Metalla, A. Koxhai, M. Mema. E Vyshka, D. Lumi Economic Development and Maritime Transport Albanian Case. Interdisciplinary Jornal of Reasearch and Development, Vol, 4. No. 12017

O. Metalla E. Vyshka, D. Lumi Defining the most important port performance indicators: a case of Albanian ports International Journal of economics, commerce and management, UK Vol. IIOI Issue 10, Oct. 2015 www.apdurres.com.al

Patric Alderton, 2008 Lloyd's practical shipping guides. Port management and operations. Third edition.

Robinson, R., 2002. Ports as elements in value-driven chain systems: the new paradigm. Maritime Policy \& Management,

UNCTAD, 1992. Development and improvement of ports: the principles of modern port management and organisation. Geneva, Switzerland: UNCTAD.

Van Schijndel, W. J. \& Dinwoodie, J., 2000. Congestion and multimodal transport: a survey of cargo transport operators in the Netherlands. Transport Policy

Woo, S-H., Pettit, S., Beresford, A. K. C., 2011a. Port evolution and performance in changing logistics environments. Maritime Economics \& Logistics. 